\title{
TRITIATED AMMONIA FORMATION (U)
}

L. K. Heung

March, 1994

Savannah River Technology Center

Westinghouse Savannah River Company

Savannah River Site

Aiken, SC 29808

Prepared For The U.S. Department Of Energy Under Contract DE-AC09-8\$SR18035 


\section{DISCLAIMER}

This work was prepared as an account of work sponsored by an agency of the United States Government. Neither the United States Government nor any agency thereof, nor any of their employees, makes any warranty, expressed or implied, or assumes any legal liability or responsibility for the accuracy, completeness, or usefulness of any information, apparatus, product, or process disclosed, or represents that its use would not infringe privately owned rights. Reference herein to any specific commercial product, process, or service by trade name, trademark, manufacturer or otherwise does not necessarily constitute or imply its endorsement, recommendation, or favoring by the United States Government or any agency thereof. The views and opinions of authors expressed herein do not necessarily reflect those of the United States Government or any agency thereof. 


\title{
TRITIATED AMMONIA FORMATION (U)
}

\author{
L. K. Heung
}

March, 1994

\section{APPROVALS AND REVIEWERS}

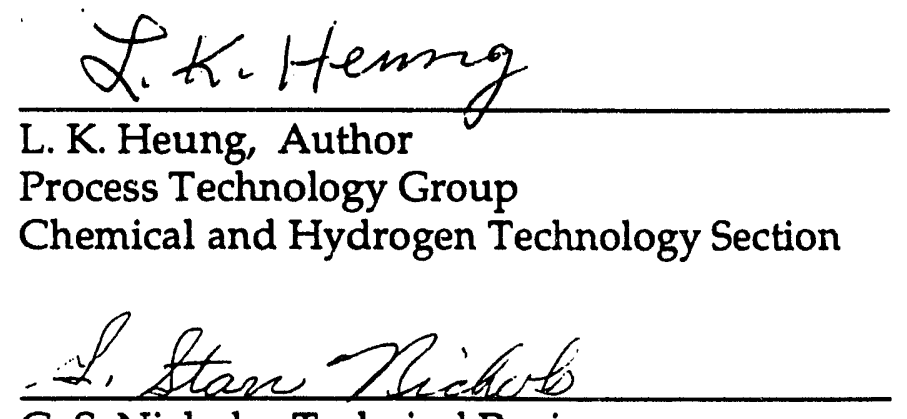

G. S. Nichols, Technical Reviewer

Process Technology Group

Chemical and Hydrogen Technology Section

T. Motyka, Manager and ADC

Process Technology Group

Chemical and Hydrogen Technology Section

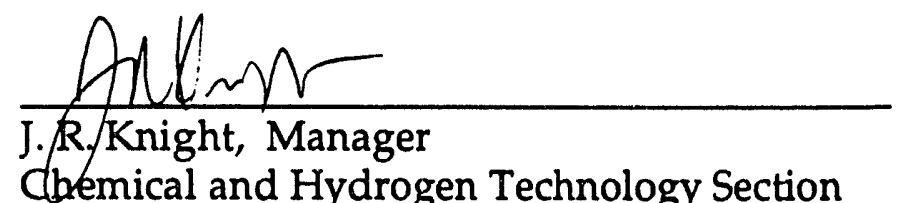

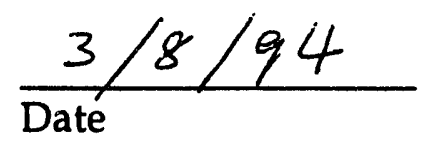

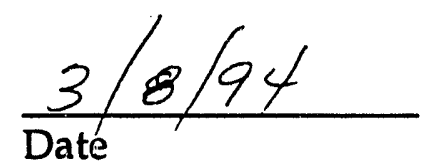

$\frac{3-9-94}{\text { Date }}$

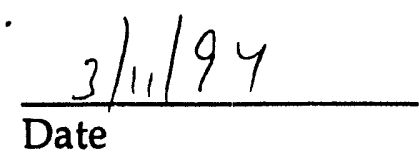




\title{
TRITIATED AMMONIA FORMATION (U)
}

\author{
L. K. Heung
}

March, 1994

\section{Introduction}

Back in 1984, when nitrogen was selected as the glovebox atmosphere for the Replacement Tritium Facility (RTF), a concern was raised as to the possibility of tritiated ammonia formation in the gloveboxes, particularly during a large tritium release. A paper by Maienschein of Lawrence Livermore Laboratory indicated that NT3 formation in a nitrogen glovebox could be significant. ${ }^{1}$ Walters at SRS reviewed the Maienschein paper, and with the help of literature data, derived a rate law for the formation of $\mathrm{NT}_{3}$ from $\mathrm{T}_{2}$ and $\mathrm{N}_{2} .{ }^{2} \mathrm{He}$ concluded that the rate of forming tritiated ammonia in a nitrogen glovebox should be thousand times smaller than what was estimated by Maienschein, therefore not a problem for the RTF gloveboxes. Later in 1991 when a set of experimental data showing tritiated ammonia formation as a function of time was produced at SRS, Walters found that his rate law did not fit the data. When he increased the rate constant by a factor of 10 , he was able to adjust his rate law to fit the first 200 hours of data, but not the data after 200 hours. ${ }^{3}$ In addition, his rate law did not predict equilibrium shown by the data.

Recently, the concern about tritiated ammonia formation came up again in the RTF. The question is how much tritiated ammonia can form in the mix tanks if there is nitrogen in the tanks. I have reviewed the works by Walters, and have developed a new rate equation which closely simulates the whole set of experimental data produced at SRS. This rate equation greatly improves our confidence in predicting the formation of tritiated ammonia under different conditions.

\section{Summary}

1. A rate equation that closely simulates experimental data has been developed. This rate equation can be used to calculate the formation of tritiated ammonia from different concentrations of tritium and nitrogen.

2. The reaction of $T_{2}$ and $N_{2}$ to form $N_{3}$ is a slow process, particularly when the tritium concentration is low. The reaction requires weeks or months to reach equilibrium dependent on the concentrations of the reactants. 


\section{Model Development}

The reaction between tritium $\left(\mathrm{T}_{2}\right)$ and nitrogen $\left(\mathrm{N}_{2}\right)$ to form tritiated ammonia (NT3) is represented by the following equation:

$$
3 \mathrm{~T}_{2}+\mathrm{N}_{2} \underset{\mathrm{k} 2}{\stackrel{\mathrm{k} 1}{\longrightarrow}} 2 \mathrm{NT}_{3}
$$

The rate equation for the formation of $\mathrm{NT}_{3}$ is written as:

$$
\text { Rate } \left.=\frac{\mathrm{d}\left[\mathrm{NT}_{3}\right]}{\mathrm{dt}}=\mathrm{k} 1 *\left[\mathrm{~T}_{2}\right]^{3} *\left[\mathrm{~N}_{2}\right]-\mathrm{k} 2 *[\mathrm{NT}]_{3}\right]^{2}
$$

where

Rate $=\mathrm{g}$-mole of $\mathrm{NT}_{3} /$ liter $/ \mathrm{hr}$

[NT3], [ $\mathrm{T}_{2}$ ], [N2] are concentrations, $\mathrm{g}$-mole/liter

$\mathrm{t}=$ time, $\mathrm{hr}$

$\mathrm{k} 1, \mathrm{k} 2=$ rate constants.

We further let

$$
\text { Rate }=\mathrm{r} \quad\left[\mathrm{NT} \mathrm{T}_{3}\right]=\mathrm{A} \quad\left[\mathrm{T}_{2}\right]=\mathrm{Tr} \quad\left[\mathrm{N}_{2}\right]=\mathrm{N} \quad \mathrm{K}=\mathrm{k} 1 / \mathrm{k} 2 .
$$

Equation (1) becomes

$$
\mathrm{r}=\mathrm{k} 1 * \mathrm{Tr}^{3} * \mathrm{~N}-\mathrm{k} 2 * \mathrm{~A}^{2}
$$

Rearranging gives:

$$
r /\left(\operatorname{Tr}^{3} * N\right)=k 1-k 2 * A^{2} /\left(\operatorname{Tr}^{3} * N\right)
$$

Equation 3 defines a straight line with the dependent variable $y=r /\left(\operatorname{Tr}^{3} * N\right)$, and the independent variable $x=A^{2} /\left(\operatorname{Tr}^{3 *} N\right)$. The slope is $-k 2$, intersect $k 1$.

With experimental data, one may calculate the values of $r, T r, N$ and $A$, Equation 3 may then be used to examine if the rate equation (Eq. 2) correctly represents the reaction. If the rate equation is correct, a plot of $y\left(=r /\left(\operatorname{Tr}^{3} * N\right)\right)$ versus $x$ $\left(=A^{2} /\left(\operatorname{Tr}^{3 *} N\right)\right)$ must be a straight line. The slope and the $y$-intersect of the line will define the values of $k 2$ and $k 1$, respectively. 


\section{Experimental Data}

An experiment was conducted at SRS to study the reaction rate between $T_{2}$ and $\mathrm{N}_{2}$ to form tritiated NT3. The experimental details and results have been documented by Walters in Reference 3 . They are briefly included here since the data will be used to examine the above rate equation.

A stainless steel container of 1.456 liter internal volume was used as the reaction vessel. A MKS Baratron Capacitance Manometer and a thermocouple, both directly inserted into the vessel, were used to measure the pressure and temperature. At time zero, 1123 torr of nitrogen and 1095 torr of tritium were charged into the vessel to start the experiment. The pressure and temperature were recorded periodically. The NT3 concentration is calculated from the pressure and temperature using equation (4) below, which is derived according to the stoichiometry of the reaction (Appendix 1):

$$
A=\frac{1}{R}\left\{\frac{\text { Pto }}{\text { To }}-\frac{P t}{T}+\frac{\text { Ptro }}{\text { To }}[1-\exp (-\lambda * t)]\right\}
$$

Where

$\mathrm{A}=[\mathrm{NT} 3]$, g-mole/liter

$\mathrm{R}=$ gas constan $\mathrm{i}, 62.4$ torr-liter $/ \mathrm{g}-\mathrm{mole} / \mathrm{K}$

Pto $=$ Total pressure at time zero, torr

$\mathrm{Pt}=$ Total pressure at time $\mathrm{t}$

Ptro=Tritium pressure at time zero, torr

To=Temperature at time zero, $\mathrm{K}$

$\mathrm{T}=$ Temperature at time $\mathrm{t}, \mathrm{K}$

$\lambda=$ Tritium decay constant, $6.43 \mathrm{E}-6 \mathrm{hr}^{-1}$

$\mathrm{t}=$ time, $\mathrm{hr}$.

The data of time, pressure and temperature, and the calculated NT3 concentration (by equation 4) are listed in Table 1. The pressure and temperature trends are also plotted in Figure 1 to show their flucturations. The fluctuations are quite significant and will contribute to the scattering of the rate of ammonia formation to be calculated below.

\section{Examination of The Rate Equation}

Equation (3) and the experimental data are used to test equation (2) for the rate equation. The rate of ammonia formation is first calculated from the data of ammonia concentration given in Table 1, using

$$
\text { Rate }=r=\frac{\Delta \mathrm{A}}{\Delta \mathrm{t}}
$$


where $\Delta \mathrm{A}$ is the increase of NT3 concentration in time $\Delta t$. The rate is plotted in Figure 2 as a function of time. Two of the 52 data points are obviously out of place and are discarded. The values for $y=r /\left(\mathrm{Tr}^{3} * N\right)$ and $x=A^{2} /\left(\mathrm{Tr}^{3} * N\right)$ are then calculated, and plotted in Figure 3 . The points are rather scattered, but the trend of a staight line is clearly shown. Regression analysis gives a straight line with a slope of -0.0900 and an intersect of 1.462. Therefore the values of the constants for the rate equation (Eq. 2) are

$$
\begin{aligned}
& \mathrm{k} 1=\text { intersect }=1.462 \\
& \mathrm{k} 2=- \text { slope }=0.0900
\end{aligned}
$$

Equation 2 becomes:

$$
\text { Rate }=\frac{\mathrm{d}\left[\mathrm{NT}_{3}\right]}{\mathrm{dt}}=1.462 *\left[\mathrm{~T}_{2}\right]^{3} *\left[\mathrm{~N}_{2}\right]-0.09 *\left[\mathrm{NT}_{3}\right]^{2}
$$

where

Rate $=$ g-mole of $\mathrm{NT}_{3} /$ liter $/ \mathrm{hr}$

[NT3], [ $\left.\mathrm{T}_{2}\right],\left[\mathrm{N}_{2}\right]$ are concentrations, g-mole/liter

$\mathrm{t}=$ time, $\mathrm{hr}$

Equation 6, as shown in Figure 4, matches the data quite well.

One may take one more step to see if Equation 6 really fits the experimental data. The ammonia concentration as a function of time is calculated using the initial concentrations of tritium and nitrogen in the experiment. The calculated results are plotted in Figure 5 in comparison with the experimental results. They are in excellent agreement for the whole duration of 1,000 hours of the experiment. Equation 6 fits the experimental data very well indeed.

\section{Application of The Rate Equation}

Equation 6 can be used to calculate the amount of $\mathrm{NT}_{3}$ formed as a function of time when the initial concentrations of $\mathrm{T}_{2}$ and $\mathrm{N}_{2}$ are known. Since it is difficult to integrate Equation 6 analytically, a numerical technique will be used here in two different cases to demonstrate its application.

(1) The first case involves the presence of nitrogen in a tritium storage tank.

Given:

Total pressure:

Gas temperature:

Initial tritium concentration:

Initial nitrogen concentration:
$2.5 \mathrm{~atm}$

$20^{\circ} \mathrm{C}$

$99.8 \mathrm{~mole} \%$

0.2 mole\% 
Calculate:

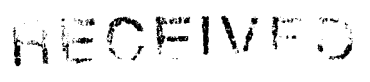

Tritiated ammonia NT3 as a function of time.

MAY 131994

The maximum NT3 that can be produced.

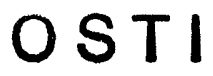

\section{Solution:}

In equation 6, the concentrations of $\mathrm{T}_{2}$ and $\mathrm{N}_{2}$ can be expressed in terms of their initial concentrations and the concentration of NT3. After that, the equation becomes a quartic function of $\mathrm{NT}_{3}$ concentration, and is difficult to solve analytically. But it can easily be solved by stepping up the time using numerical techniques.

At time $\mathrm{t}=\mathrm{to}=0$,

the concentrations of tritium and nitrogen in terms of g-mole/liter are:

$\left[\mathrm{T}_{2}\right]_{0}=0.998^{*}\left(2.5^{*} 1 /(1 * 22.4 / 1 / 273)\right) /(273+20)=0.103781 \mathrm{~g}-\mathrm{mole} / \mathrm{liter}$

$\left[\mathrm{N}_{2}\right]_{0}=0.002^{*}\left(2.5^{*} 1 /(1 * 22.4 / 1 / 273)\right) /(273+20)=0.000208 \mathrm{~g}$-mole $/$ liter

$[\mathrm{He}-3]_{\mathrm{O}}=0 \mathrm{~g}$-mole $/$ liter

$[\mathrm{NT} 3]_{0}=0$ g-mole $/$ liter

and the rate of ammonia formation at time zero is, using Equation 6:

$$
\begin{aligned}
\text { Rate }_{\mathrm{o}} & =\mathrm{k} 1^{*}\left[\mathrm{~T}_{2}\right]_{\mathrm{o}}{ }^{3 *}\left[\mathrm{~N}_{2}\right]_{\mathrm{o}}-\mathrm{k} 2^{*}\left[\mathrm{NT}_{3}\right]_{\mathrm{o}}{ }^{2} \\
& =1.462^{*} 0.103781^{3 * 0} 0.000208-0.09^{*} 0^{2} \\
& =3.40 \mathrm{E}-7 \mathrm{~g}-\mathrm{mole} / \mathrm{liter} / \mathrm{hr}
\end{aligned}
$$

At time $t=t_{1}=t o+\Delta t, \Delta t$ is a small increment of time, the ammonia formed is $\Delta\left[\mathrm{NT}_{3}\right]_{1}=$ Rate $^{*} \Delta \mathrm{t}=3.4 \mathrm{E}-7^{*} \Delta \mathrm{t}$ g-mole $/$ liter,

the concentrations of the gases are

$\left[\mathrm{T}_{2}\right]_{1}=\left[\mathrm{T}_{2}\right]_{0}-\Delta\left[\mathrm{NT}_{3}\right]_{1} * 3 / 2-[\mathrm{He}-3]_{1} / 2 \mathrm{~g}$-mole $/$ liter

$\left[\mathrm{N}_{2}\right]_{1}=\left[\mathrm{N}_{2}\right]_{0}-\Delta\left[\mathrm{NT}_{3}\right]_{1}{ }^{*} 1 / 2 \mathrm{~g}$-mole $/$ liter

$[\mathrm{He}-3]_{1}=2 *\left[\mathrm{~T}_{2}\right]_{\mathrm{o}} *\left(1-\exp \left(-0.00000643^{*} \mathrm{t}\right) \mathrm{g}\right.$-mole $/$ liter

$\left[\mathrm{NT}_{3}\right]_{1}=\left[\mathrm{NT}_{3}\right]_{0}+\Delta\left[\mathrm{NT}_{3}\right]_{1} \mathrm{~g}$-mole $/$ liter

and the rate of ammonia formation is

Rate $1=k 1 *\left[T_{2}\right]_{1}{ }^{3 *}\left[\mathrm{~N}_{2}\right]_{1}-\mathrm{k} 2 *\left[\mathrm{NT}_{3}\right]_{1}{ }^{2}$

The steps are repeated to calculate the concentration of $\mathrm{NT}_{3}$ as a function of time. The results are plotted in Figure 6 . This figure shows that the formation of ammonia is very slow. It takes about 860 hours ( 35 days) to convert half of the nitrogen to tritiated ammonia, and much more than 1000 hours ( 40 days) to reach equilibrium.

The maximum concentration of ammonia is reached when the reaction arrives at equilibrium. At equilibrium, Equation 6 equals zero:

$$
\text { Rate }=k 1 *\left[T_{2}\right]^{3 *}\left[\mathrm{~N}_{2}\right]-k 2 *\left[\mathrm{NT}_{3}\right]^{2}=0
$$


or

$\left[\mathrm{NT}_{3}\right]^{2} /\left(\left[\mathrm{T}_{2}\right]^{3 *}\left[\mathrm{~N}_{2}\right]\right)=\mathrm{k} 1 / \mathrm{k} 2=1.462 / 0.09=16.2$

Since

$\left[\mathrm{T}_{2}\right]=\left[\mathrm{T}_{2}\right]_{0}-[\mathrm{NT} 3]^{* 3 / 2}$

and $\left[\mathrm{N}_{2}\right]=\left[\mathrm{N}_{2}\right]_{0}-\left[\mathrm{NT}_{3}\right]^{*} 1 / 2$

(Tritium decay neglected)

Substituting the above into equation (7):

$$
\left[\mathrm{NT}_{3}\right]^{2} /\left(\left[\mathrm{T}_{2}\right]_{0}-\left[\mathrm{NT}_{3}\right]^{* 3 / 2}\right)^{3} /\left(\left[\mathrm{N}_{2}\right]_{0}-[\mathrm{NT} 3]^{* 1 / 2}\right)=16.2
$$

Solving Equation 8 above will give the maximum concentration of NT3.

Equation 8 is a quartic equation and is better solved by trial-and-error, since we know that the maximum of NT3 must be within 0 to ${ }^{*}\left[\mathrm{~N}_{2}\right]_{0}(0$ to $0.000416 \mathrm{~g}-$ mole/liter). We find that when NT3 is $0.000398 \mathrm{~g}$-mole/liter, the left side of Equation 8 equals 16.2 the same as the value of $K$. Therefore the maximum NT3 concentration is $0.000398 \mathrm{~g}$-mole/liter At that point $96 \%$ of the nitrogen will have been converted to NT3. It takes much more than 40 days $(=1,000 / 24)$ io reach this equilibrium.

(2) The second case involves the release of $10 \mathrm{~g}$ of tritium into a $600 \mathrm{ft}^{3}$ nitrogen atmosphere glovebox.

Given:

Glovebox volume:

$600 \mathrm{ft}^{3}$

Total pressure:

$1 \mathrm{~atm}$

Gas temperature:

$20^{\circ} \mathrm{C}$

Initial tritium quantity:

$10 \mathrm{~g}$

\section{Calculate:}

Tritiated ammonia NT3 as a function of time.

The maximum NT3 that can be produced.

\section{Solution:}

At time zero,

the concentrations of tritium and nitrogen in terms of $g$-mole/liter are:

$\left[\mathrm{T}_{2}\right]_{0}=10 / 6 /(600 * 28.32)=9.81 \mathrm{E}-5 \mathrm{~g}$-mole $/$ liter

$\left[\mathrm{N}_{2}\right]_{0}=1 * 1 /(1 * 22.4 / 273) /(273+20)-9.81 \mathrm{E}-5=0.041 \mathrm{~g}$-mole $/$ liter

$[\mathrm{He}-3]_{0}=0 \mathrm{~g}$-mole $/$ liter

$[\mathrm{NT}]_{0}=0$ g-mole $/$ liter

and the rate of ammonia formation at time zero is, using equation (5):

$$
\begin{aligned}
\text { Rateo }_{0} & =\mathrm{k} 1 *\left[\mathrm{~T}_{2}\right]_{0}{ }^{3 *}\left[\mathrm{~N}_{2}\right]_{0}-\mathrm{k} 2 *\left[\mathrm{NT}_{3}\right]_{0}{ }^{2} \\
& =1.462^{*} 9.81 \mathrm{E}-5^{3 *} 0.041-0.09 * 0^{2}
\end{aligned}
$$


Using the same method as above to calculate the amount of NT3 as a function of time. The results are plotted in Figure 7. In comparison with the mix tank case, the formation of $\mathrm{NT}_{3}$ is 7 orders of magnitude slower in the glovebox case. It takes about 100 hours to produce $5.7 \mathrm{E}-12 \mathrm{~g}$-mole/liter of NT3, which is $9.7 \mathrm{E}-8 \mathrm{~g}$ mole in the $600 \mathrm{ft}^{3}$ glovebox $(5.7 \mathrm{E}-12 * 28.32 * 600)$.

At equilibrium, the $\mathrm{NT}_{3}$ concentration is $7.8 \mathrm{E}-7 \mathrm{~g}-\mathrm{mol} / \mathrm{liter}$, or $7.8 \mathrm{E}-7 * 3 / 2 / 9.81 \mathrm{E}-$ $5=1.19 \%$ of the $\mathrm{T}_{2}$ is converted to NT3.

\section{The Effect of $T_{2}$ Concentration}

Equations 6 and 7 indicate that the concentration of $T_{2}$ has the strongest effect on both the NT3 formation rate and the maximum concentration of NT3 at equilibrium. To illustrate the magnitude of this effect, a mixture of $T_{2}$ and $N_{2}$ at 1 atm total pressure, and $20{ }^{\circ} \mathrm{C}$ temperature can be considered. When the $\mathrm{T}_{2}$ concentration increases from 0 to $100 \%$, the rate of $\mathrm{NT}_{3}$ formation increases from zero, through a maximum of $4 \mathrm{E}-7 \mathrm{~g}-\mathrm{mol} / \mathrm{liter} / \mathrm{hr}$, then back to zero. The maximum rate occurs when the tritium concentration is about $7 \% \%$. See Figure 8 .

An increase in total pressure increases the concentration which increases the rate. When the total pressure is increased from $1 \mathrm{~atm}$ to $3 \mathrm{~atm}$, the maximum rate increase by two orders of magnitude, to about $3 E-5 \mathrm{~g}-\mathrm{mol} / \mathrm{liter} / \mathrm{hr}$. See Figure 8 .

The effect of tritium concentration on the equilibrium concentration of $\mathrm{NT}_{3}$ and the maximum amount of $\mathrm{T}_{2}$ converted to $\mathrm{NT}_{3}$ is shown in Figure 9. This figure shows that, at $1 \mathrm{~atm}$ total pressure, the equilibrium concentration of NT3 attains a maximum of $0.0018 \mathrm{~g}$-mole/liter at a $\mathrm{T}_{2}$ fraction of 0.7 . The maximum conversion of $T_{2}$ is 0.1 fraction at a $T_{2}$ fraction of 0.4 .

The maximum conversion of $\mathrm{T}_{2}$ for several particular cases of intrest are given in Table 2.

\section{Comparissons To The Walters Model}

In reference 2, Walters proposed the following rate law for the formation of NT3 from $\mathrm{T}_{2}$ and $\mathrm{N}_{2}$ :

$$
\text { Rate }=\frac{\mathrm{d}\left[\mathrm{NT}_{3}\right]}{\mathrm{dt}}=\frac{2 * \mathrm{k} 1 * \varnothing * 57.8 *\left[\mathrm{~N}_{2}\right] *\left[\mathrm{~T}_{2}\right]^{2}}{1+\varnothing *\left[\mathrm{~T}_{2}\right]}
$$

where $\mathrm{k} 1=4.23 \mathrm{E}-6$, and $\varnothing=58.14$. 
As described in reference 2, equation (9) was analytically integrated to yield an approximation to show the NT3 concentration as a function of time:

$$
\left[\mathrm{NT}_{3}\right]=\frac{2^{*} \mathrm{~A}^{*} B[1-\exp (-\mathrm{kt})]}{3^{*} B-A^{*}[\exp (-k t)]}
$$

where, $A=\left[T_{2}\right] 0, B=\left[N_{2}\right] 0, k=3.56 \mathrm{E}-5$.

Equation 10 does not fit the data given in Table 1. The calculated concentration of $\mathrm{NT}_{3}$ is much smaller than the data. When the value of $k$ is multiplied by a factor of 10, Equation 8 fits the early part of the data up to about 200 hours. After that the calculated value becomes much higher than the data. Another difficulty with equations 9 and 10 is that the decomposition of NT3 has not been taken into account. The equations do not predict an equilibrium and the reaction will go to completion, contrary to the experimetal data. The data show that there is an equilibrium, when only about $23 \%$ of the tritium is converted to NT3. Walters' model, the model of this work and the data are compared in Figure 10.

\section{Comparisons To The Maienschein Model}

In reference 1, Maienschein of LLNL considered the release of tritium into a nitrogen glovebox and proposed the following rate equation:

$$
\mathrm{NT} 3 \text { rate }=3.54 \mathrm{E}-12 * \mathrm{M} \quad \mathrm{mole} / \mathrm{sec}
$$

where $M$ is curies of tritium in a volume $V$. The equation was developed by assuming that all the $B$ particles are absorbed by the nitrogen and that the $G$ factor for NT3 formation is 1 . The $G$ factor is defined as the number of molecules produced per $100 \mathrm{eV}$ of energy absorbed. This equation shows that the rate is dependent on the tritium concentration alone, and is independent of $\mathrm{N}_{2}$ and $\mathrm{NT}_{3}$ concentrations.

To compare with the rate equation of this work, we let $V=1$ liter and change the units:

$$
\begin{aligned}
& M(\text { curies } / \text { liter })=\left[T_{2}\right](\text { moles } / \text { liter }) * 6 * 9600 \\
& 1 \text { hour }=3600 \text { seconds. }
\end{aligned}
$$

Equation (11) becomes

$$
\begin{aligned}
{\left[\mathrm{NT}_{3}\right] \text { rate } } & =3.54 \mathrm{E}-12 * 6 * 9600 * 3600 *\left[\mathrm{~T}_{2}\right] \\
& =7.34 \mathrm{E}-4 *\left[\mathrm{~T}_{2}\right] \quad \mathrm{mole} / \mathrm{liter} / \mathrm{hr}
\end{aligned}
$$

The NT3 formation rates for 3 cases are calculated with Equation 12 and Equation 6 respectively, and are compared in Table 3. 
Table 3 shows that the Maienschein model overestimates the rates for cases that involve both low and high tritium concentrations. This is consistent with his assumptions. He assumed that all the $B$ particles are absorbed by the nitrogen atoms and that the $\mathrm{G}$ factor for NT3 formation is 1 . These assumptions are most likely to be met when the ratio of $\mathrm{T}_{2}$ to $\mathrm{N}_{2}$ is about 1 . When the ratio is much smaller or larger than 1 , it is most likely that only a fraction of the $B$ particles are absorbed by the nitrogen, or only a fraction of those absorbed can form NT3.

On the percent ige of tritium that can be converted to $\mathrm{NT}_{3}$ in a nitrogen glovebox situation, Maier schein estimated a minimum of $10 \% \mathrm{~T}_{2}$ will be converted to NT3 in about 80 hous s. This work shows that the final conversion is dependent on the concentrations $\mathrm{Cf} \mathrm{T}_{2}$ and $\mathrm{N}_{2}$. The maximum conversion of tritium is about $10 \%$ which occurs when the initial ratio of $\mathrm{T}_{2}$ and $\mathrm{N}_{2}$ is about 0.4 (see Figure 9). Equilibrium takes weeks and months, dependent on the $\mathrm{T}_{2}$ concentration (see Figures 6 and 7).

\section{The Effect of Oxygen and Other Gases}

The reaction between $\mathrm{T}_{2}$ and $\mathrm{O}_{2}$ at high tritium concentrations was studied by Dorfman, and a first order rate equation was established: 4

$$
R=k^{*}\left[T_{2}\right]
$$

where

$$
\mathrm{k}=1.2 \mathrm{E}-4 / \mathrm{min}=7.2 \mathrm{E}-3 / \mathrm{hr}
$$

$\left[\mathrm{T}_{2}\right]=$ tritium concentration

In the case of a mix tank of tritium at $2.5 \mathrm{~atm}$ and $20^{\circ} \mathrm{C}$, containing a small amount of oxygen and nitrogen, the tritium concentration is $0.1 \mathrm{~g}$-mol/liter (see Table 2). The rate of converting $\mathrm{T}_{2}$ to $\mathrm{T}_{2} \mathrm{O}$ is calculated by equation 13:

$$
7.2 \mathrm{E}-3^{*} 0.1=\text { to be } 7.2 \mathrm{E}-4 \mathrm{~g}-\mathrm{mol} / \mathrm{liter} / \mathrm{hr} \text {, }
$$

which is much faster than the NT3 formation rate of 3.4E-7 g-mole/liter/hr (see Table 2). Therefore in the presence of both $\mathrm{O}_{2}$ and $\mathrm{N}_{2}, \mathrm{~T}_{2} \mathrm{O}$ will form before NT3.

At low tritium concentrations, Casaletto et al found a second order reaction rate equation:4

where

$$
\mathrm{R}=\mathrm{k}^{*}\left[\mathrm{~T}_{2}\right]^{2}
$$

$\mathrm{k}=6.2 \mathrm{E}-4 \mathrm{ml} / \mathrm{mCi} / \mathrm{hr}=35.7 \mathrm{~g}-\mathrm{mole} / \mathrm{liter} / \mathrm{hr}$

( $1 \mathrm{mCi} / \mathrm{ml}=1.736 \mathrm{E}-5 \mathrm{~g}-\mathrm{mole} /$ liter)

(1 g-mole $/$ liter $=57600 \mathrm{mCi} / \mathrm{ml}$ ) 
For $10 \mathrm{~g} \mathrm{~T}_{2}$ released to a $600 \mathrm{ft}^{3}$ nitrogen glovebox, the $\mathrm{T}_{2}$ concentration is $9.8 \mathrm{E}-5$ $\mathrm{g}$-mole/liter. From equation 12, the $\mathrm{T}_{2} \mathrm{O}$ formation rate is

$35.7^{*}(9.8 \mathrm{E}-5)^{2}=3.4 \mathrm{E}-7 \mathrm{~g}-\mathrm{mole} / \mathrm{liter} / \mathrm{hr}$

which is again much larger than the NT3 formation rate of $5.7 \mathrm{E}-14 \mathrm{~g}$ mole/liter/hr (see Table 2). Therefore at low tritium concentration, $\mathrm{T}_{2} \mathrm{O}$ forms before NT 3 also.

When theie are other gases other than $\mathrm{T}_{2}, \mathrm{O}_{2}$ and $\mathrm{N}_{2}$ present, such as $\mathrm{He}_{2} \mathrm{D}_{2}$ and $\mathrm{H}_{2}$. there should at least be a dilution effect, which would lower the NT3 formation rate. Therefore the rate equation presented in this work should define the upper bound for these mixtures. More data will be required to define the quantitative effects of these other gases.

\section{References}

1. Jon L. Maienschein, "Radiolysis in Nitrogen-Tritium Mixtures: Formation of Ammonia in a Nitrogen-Atmosphere Glovebox", UCRL-90645, 4/84.

2. R. T. Walters, "Ammonia Formation in Nitrogen-Tritium Systems" DPST-85$553,6 / 30 / 85$.

3. R. T. Walters, "Kinetics and Mechanism for the Radiolytic Formation of NT3" WSRC-TR-91-390, 5/29/91.

4. G. J. Casaletto, L. H. Gevantman and J. B. Nash, "The Self-Radiation Oxidation of Tritium in Oxygen and Air", USNRDL-TR-565, Naval Radiol. Def. Lab., San Francisco, CA, 1962. 
Table 1 Experimental Data of Tritiated Ammonia Formation (Reference 3)

Tritiated Ammonia Formation Data

(Data from R. T Waters, WSRC-TR-91-390, 5/29/91)

Total pressure at time zero $=2218$ torr

Total volume $=1.456$ Liter

$[\mathrm{T} 2]_{\mathrm{o}}=0.061 \mathrm{~g}-\mathrm{mol} / \mathrm{L}$

$[\mathrm{N} 2] \mathrm{o}=0.062 \mathrm{~g}-\mathrm{mol} / \mathrm{L}$

\begin{tabular}{|c|c|c|c|c|c|c|c|}
\hline $\begin{array}{c}\text { Time } \\
\mathrm{hr}\end{array}$ & $\begin{array}{c}P \\
\text { torr }\end{array}$ & $\begin{array}{l}\mathrm{T} \\
{ }^{\circ} \mathrm{C} \\
\end{array}$ & $\begin{array}{c}{[\mathrm{NT3}]} \\
\mathrm{g}-\mathrm{mol} / \mathrm{L}\end{array}$ & $\begin{array}{c}\text { Time } \\
\mathrm{hr}\end{array}$ & $\begin{array}{c}P \\
\text { torr }\end{array}$ & $\begin{array}{l}\mathrm{T} \\
{ }^{\circ} \mathrm{C} \\
\end{array}$ & $\begin{array}{c}{[\mathrm{NT3}]} \\
\mathrm{g}-\mathrm{mol} / \mathrm{L}\end{array}$ \\
\hline 0 & 2218 & 16.8 & 0 & 642.70 & 2069 & 15.6 & 0.0080 \\
\hline 19.00 & 2190 & 14.3 & 0.0005 & 650.10 & 2080 & 17.3 & 0.0081 \\
\hline 25.42 & 2220 & 18.4 & 0.0006 & 666.72 & 2080 & 17.7 & 0.0083 \\
\hline 90.92 & 2168 & 15.2 & 0.0021 & 674.33 & 2094 & 19.7 & 0.0083 \\
\hline 98.00 & 2173 & 16.1 & 0.0022 & 691.92 & 2080 & 18.8 & 0.0087 \\
\hline 114.92 & 2158 & 15.0 & 0.0026 & 698.22 & 2073 & 17.2 & 0.0085 \\
\hline 122.00 & 2162 & 15.9 & 0.0028 & 762.97 & 2092 & 20.6 & 0.0088 \\
\hline 188.75 & 2151 & 16.8 & 0.0038 & 770.33 & 2054 & 15.2 & 0.0087 \\
\hline 193.83 & 2172 & 19.6 & 0.0038 & 786.70 & 2057 & 15.4 & 0.0087 \\
\hline 255.12 & 2152 & 18.9 & 0.0046 & 794.17 & 2054 & 15.1 & 0.0087 \\
\hline 260.35 & 2122 & 15.0 & 0.0047 & 810.75 & 2055 & 15.4 & 0.0088 \\
\hline 284.47 & 2118 & 15.0 & 0.0049 & 818.20 & 2056 & 15.7 & 0.0088 \\
\hline 289.95 & 2143 & 18.4 & 0.0049 & 835.27 & 2049 & 14.8 & 0.0089 \\
\hline 306.80 & 2115 & 15.1 & 0.0051 & 842.08 & 2050 & 14.9 & 0.0089 \\
\hline 313.50 & 2127 & 16.8 & 0.0052 & 858.78 & 2041 & 13.7 & 0.0089 \\
\hline 355.32 & 2107 & 15.1 & 0.0056 & 866.37 & 2066 & 17.0 & 0.0088 \\
\hline 362.20 & 2116 & 16.4 & 0.0056 & 930.38 & 2043 & 14.5 & 0.0091 \\
\hline 428.50 & 2092 & 14.3 & 0.0061 & 938.37 & 2063 & 17.3 & 0.0091 \\
\hline 433.82 & 2118 & 18.0 & 0.0062 & 955.03 & 2061 & 17.0 & 0.0091 \\
\hline 451.78 & 2089 & 14.4 & 0.0063 & 961.83 & 2053 & 16.0 & 0.0092 \\
\hline 457.88 & 2116 & 18.1 & 0.0063 & 978.83 & 2056 & 16.5 & 0.0092 \\
\hline 474.85 & 2091 & 15.1 & 0.0065 & 1006.82 & 2084 & 20.1 & 0.0091 \\
\hline 481.97 & 2100 & 16.8 & 0.0067 & & & & \\
\hline 498.83 & 2087 & 15.4 & 0.0069 & & & & \\
\hline 506.12 & 2104 & 19.4 & 0.0075 & & & & \\
\hline 522.65 & 2066 & 15.0 & 0.0079 & & & & \\
\hline 530.23 & 2077 & 16.5 & 0.0079 & & & & \\
\hline 594.70 & 2067 & 14.8 & 0.0078 & & & & \\
\hline 602.33 & 2076 & 15.9 & 0.0077 & & & & \\
\hline 618.78 & 2071 & 15.6 & 0.0079 & & & & \\
\hline 625.92 & 2084 & 17.3 & 0.0079 & & & & \\
\hline
\end{tabular}


WSRC-TR-94-0132

Table 2 Effect of Concentration on Maximum Conversion

\begin{tabular}{|c|c|c|c|}
\hline & $\begin{array}{c}{\left[\mathrm{T}_{2}\right]} \\
\text { (g-mole/liter) } \\
\end{array}$ & $\begin{array}{c}{\left[\mathrm{N}_{2}\right]} \\
\text { (g-mole/liter) } \\
\end{array}$ & $\begin{array}{c}\text { Maximum } \\
\text { conversion } \\
\left(\% \mathrm{~T}_{2} \text { converted }\right)\end{array}$ \\
\hline $\begin{array}{r}10^{-2} \mu \mathrm{Ci} / \mathrm{cc} \mathrm{T}_{2} \\
\text { in } \mathrm{N}_{2} \text { glovebox }\end{array}$ & $1.74 \mathrm{E}-10$ & 0.041 & $1.6 \mathrm{E}-05$ \\
\hline $0.2 \% \mathrm{~N}_{2}$ in $\mathrm{T}_{2}$ at $2.5 \mathrm{~atm}$ & 0.103781 & 0.000208 & $\begin{array}{c}0.58 \% \\
\left(95.7 \% \mathrm{~N}_{2}\right)\end{array}$ \\
\hline $\begin{array}{c}10 \mathrm{~g} \mathrm{~T}_{2} \text { in } 600 \mathrm{ft}^{3} \mathrm{~N}_{2} \\
(1 \mathrm{~atm})\end{array}$ & $9.81 \mathrm{E}-5$ & 0.041 & 1.2 \\
\hline $\begin{array}{c}177 \mathrm{~g} \mathrm{~T}_{2} \text { in } 600 \mathrm{ft} 3 \mathrm{~N}_{2} \\
(1 \mathrm{~atm})\end{array}$ & 0.017 & 0.024 & 10.2 \\
\hline $\begin{array}{l}\text { Experimental case } \\
\text { (total } P=2218 \text { torr) }\end{array}$ & 0.06 & 0.06 & 23.3 \\
\hline
\end{tabular}


Table 3 Comparison of the Rate Equations

\begin{tabular}{|c|c|c|}
\hline & \multicolumn{2}{|c|}{$\begin{array}{c}{\left[\mathrm{NT}_{3}\right] \text { rate }} \\
(\mathrm{g}-\mathrm{mol} / \mathrm{liter} / \mathrm{hr})\end{array}$} \\
\hline & $\begin{array}{l}\text { This Work } \\
\text { Eq. } 6 \\
\text { G factor= } \\
\text { ([T2], [N2], } \\
\left.\left[\mathrm{NT}_{3}\right]\right)\end{array}$ & $\begin{array}{l}\text { Maienschein } \\
\text { Eq. } 12 \\
\text { G factor }=1\end{array}$ \\
\hline (1) $10-2 \mu \mathrm{Ci} / \mathrm{cc} \mathrm{T}_{2}$ in $\mathrm{N}_{2}$ glovebox & 3.2E-31 & $12.8^{*} \mathrm{E}-14$ \\
\hline (2) $\begin{array}{c}10 \mathrm{~g} \mathrm{~T}_{2} \text { in } 600 \mathrm{ft}^{3} \mathrm{~N}_{2} \text { glovebox } \\
{\left[\mathrm{T}_{2}\right]=9.8 \mathrm{E}-5 \mathrm{~g} \text {-mol / liter }} \\
{\left[\mathrm{N}_{2}\right]=0.0415 \mathrm{~g} \text {-mol/liter }}\end{array}$ & $5.7 \mathrm{E}-14$ & $71.9 \mathrm{E}-9$ \\
\hline $\begin{array}{l}\text { (3) } 2218 \text { torr total pressure (data case) } \\
{\left[\mathrm{T}_{2}\right]=0.06 \mathrm{~g} \text {-mol } / \text { liter }} \\
{\left[\mathrm{N}_{2}\right]=0.06 \mathrm{~g}-\mathrm{mol} / \mathrm{liter}}\end{array}$ & $1.9 \mathrm{E}-5$ & $4.4 \mathrm{E}-5$ \\
\hline $\begin{array}{l}\text { (4) } 99.8 \mathrm{~mol} \% \mathrm{~T}_{2}, 0.2 \mathrm{~mol} \% \mathrm{~N}_{2}, 2.5 \mathrm{~atm} \\
{\left[\mathrm{~T}_{2}\right]=0.103 \mathrm{~g} \text {-mol } / \text { liter }} \\
{\left[\mathrm{N}_{2}\right]=0.00021 \mathrm{~g} \text {-mol } / \text { liter }}\end{array}$ & 3.4E-7 & $7.6 \mathrm{E}-5$ \\
\hline
\end{tabular}




\section{Experimental Data}

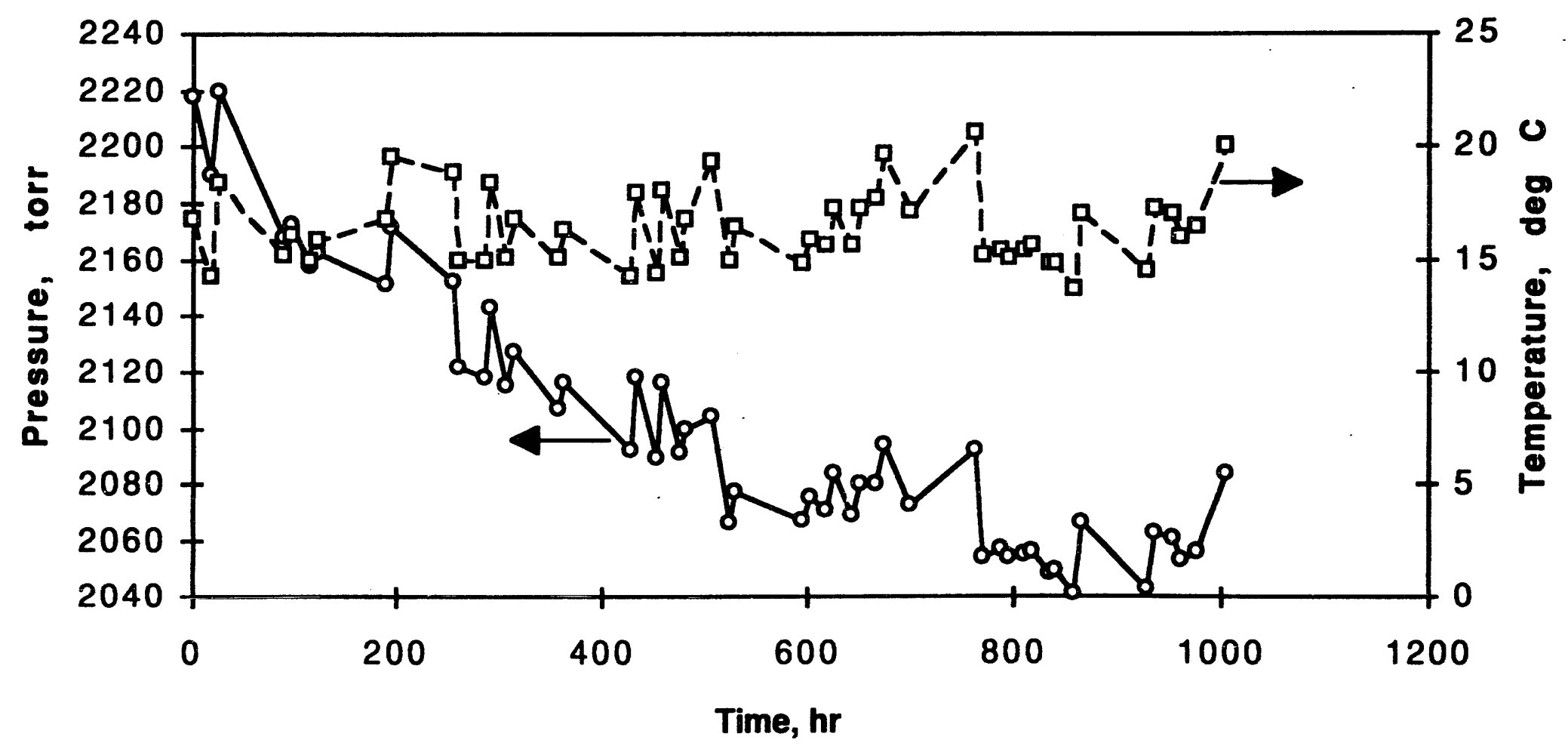

Figure 1 Tritiated Ammonia Formation Experimental Data 


\section{NT3 Formation Rate Data}

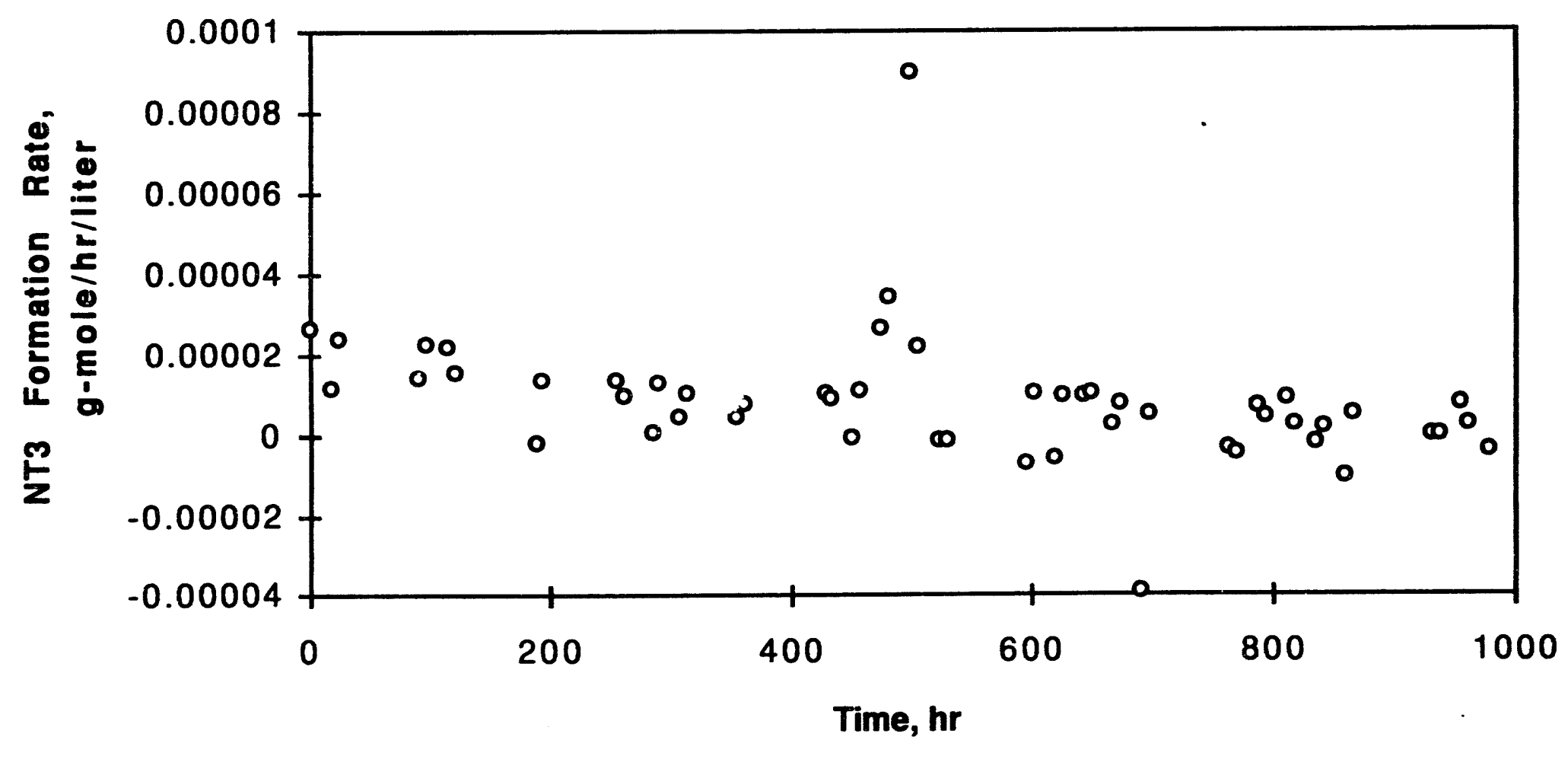

Figure 2. Rate Data Calculated From The Experimental Data 


\section{To Find The Constants}

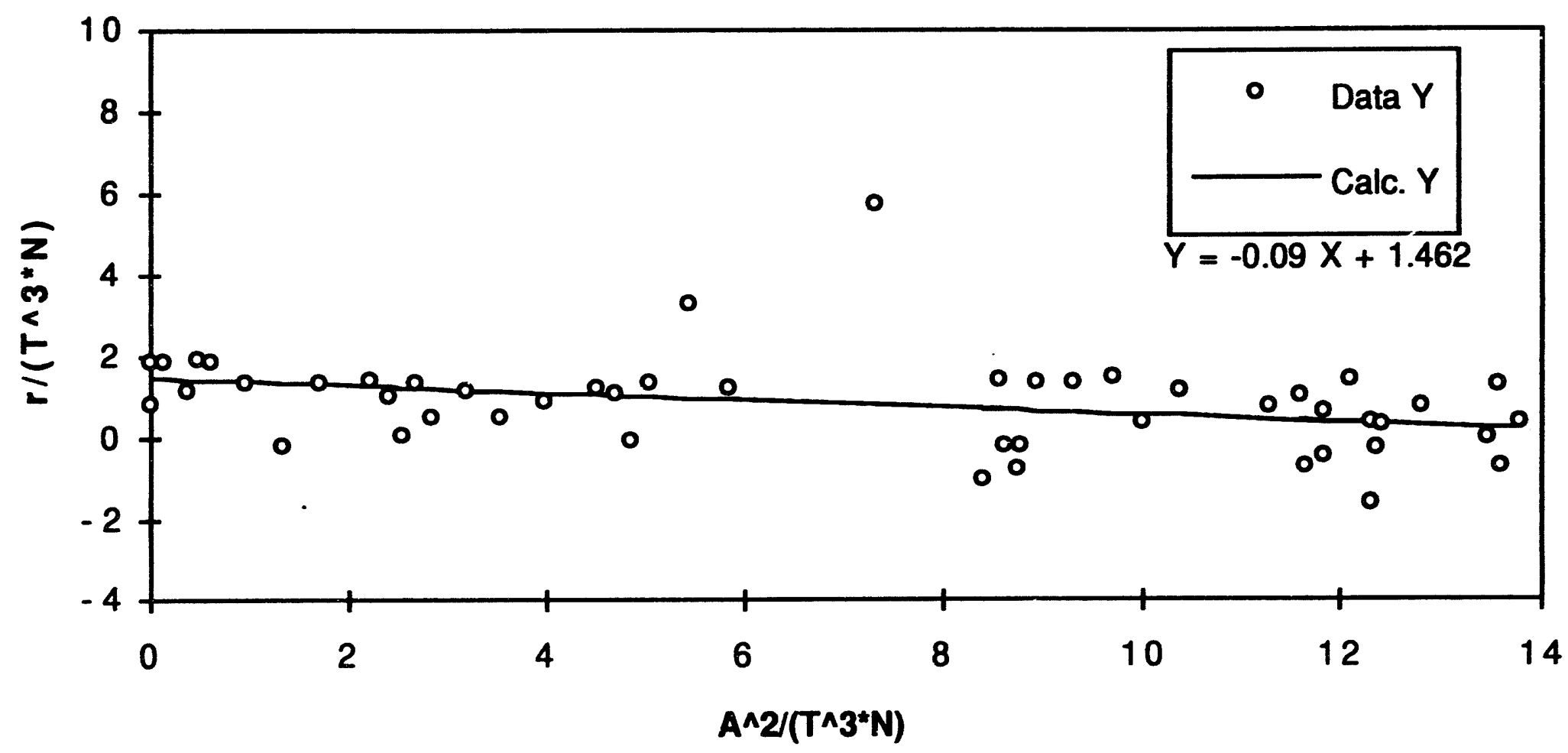

Figure 3. The Rate Equation Constants 


\section{NT3 Formation Rate - Data vs. Equation}

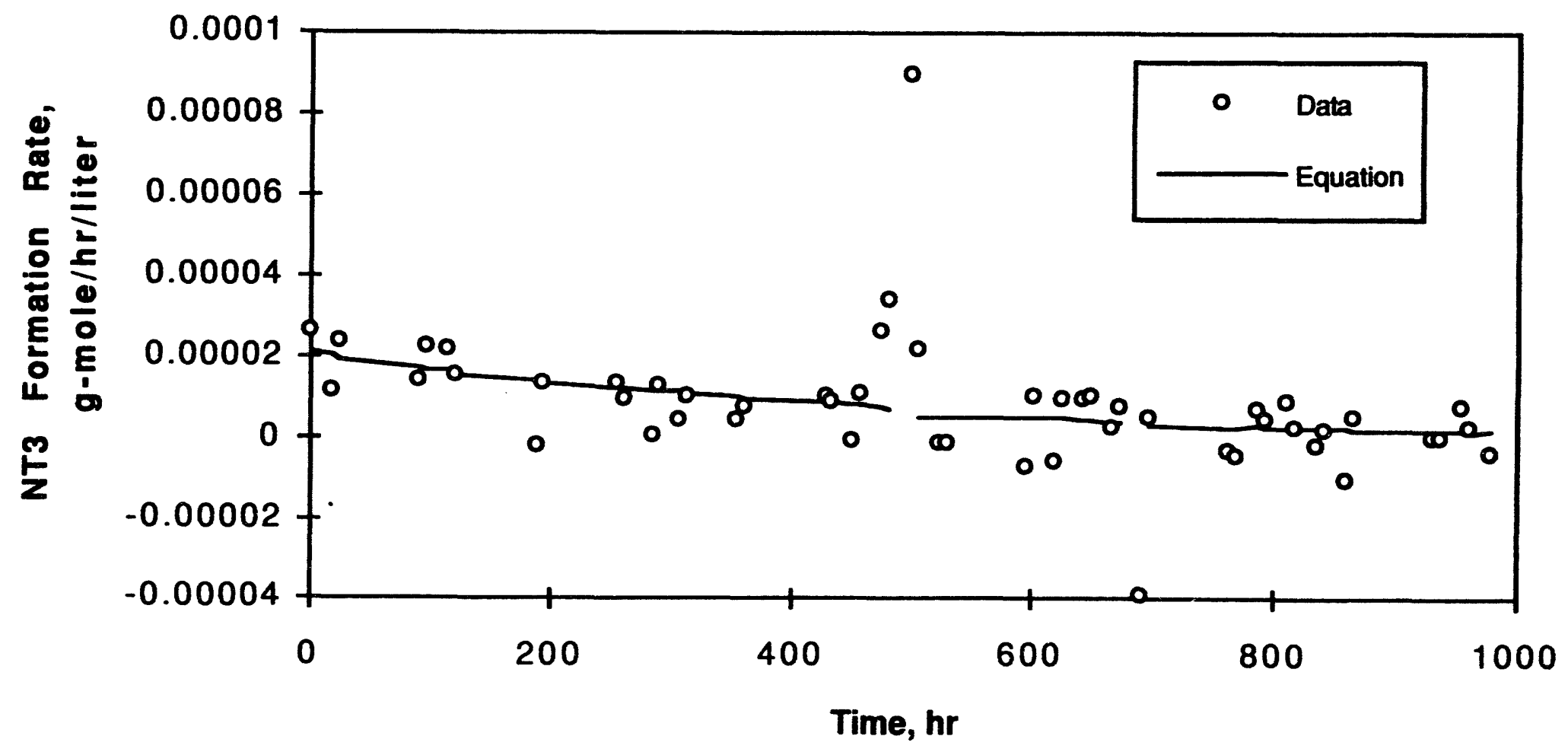

Figure 4. Rate Data vs. The Rate Equation 


\section{Experimental Data vs Calculation}

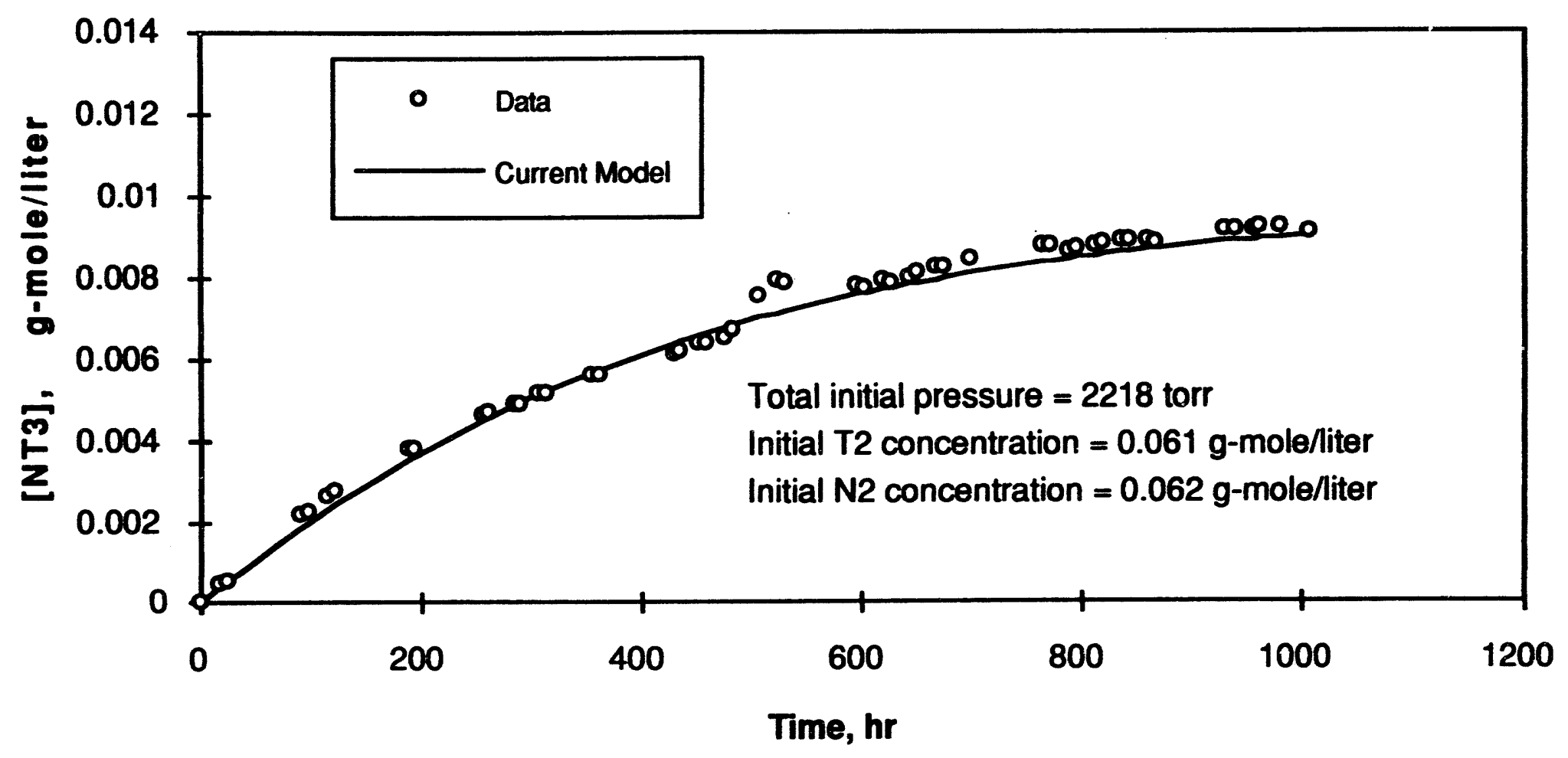

Figure 5 Tritiated Ammonia Formation Data vs. Calculation With The Rate Equation 


\section{Ammonia Formation In A Mix Tank}

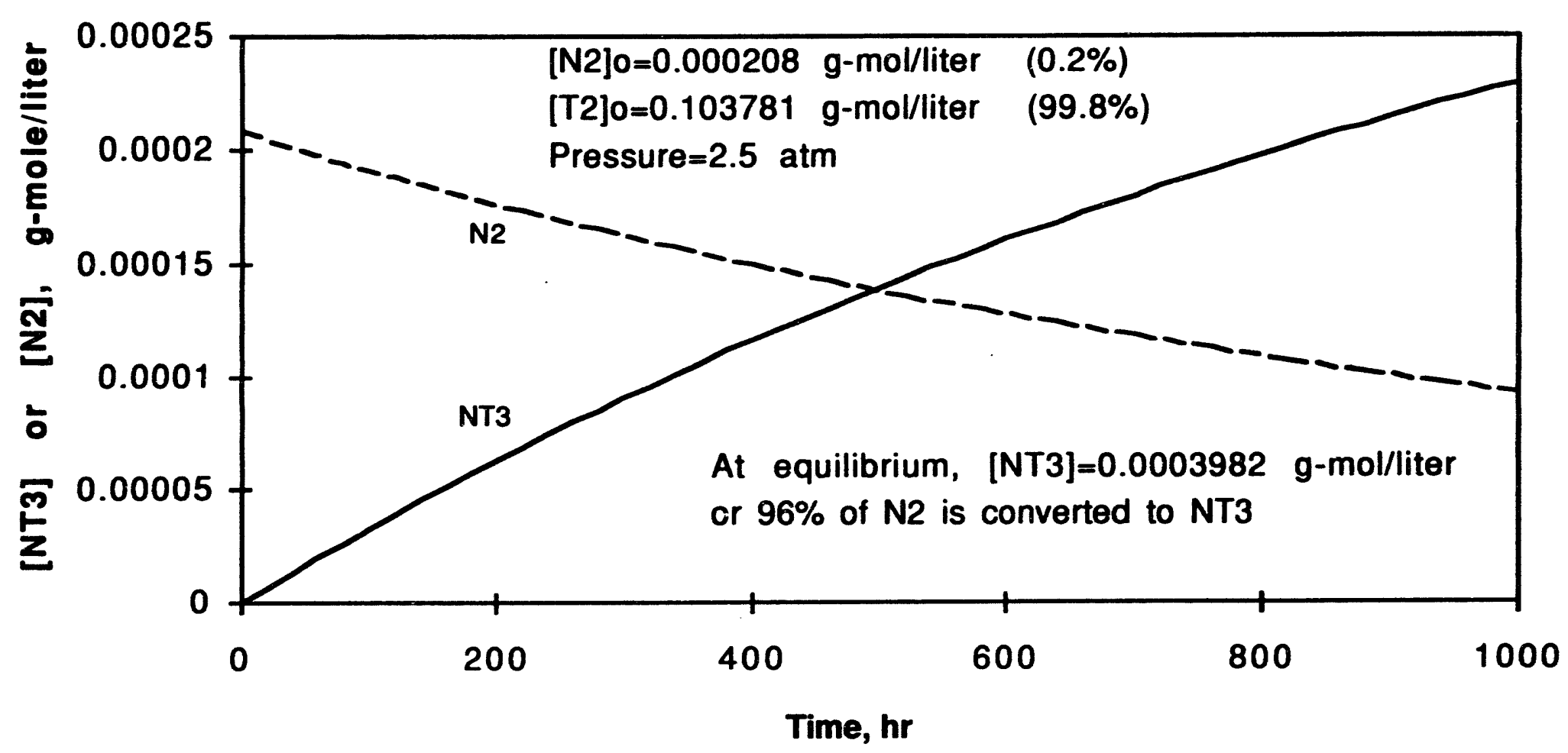

Figure 6. Tritiated Ammonia Formation in A Mix Tank 


\section{Ammonia Formation In A Nitrogen Glovebox}

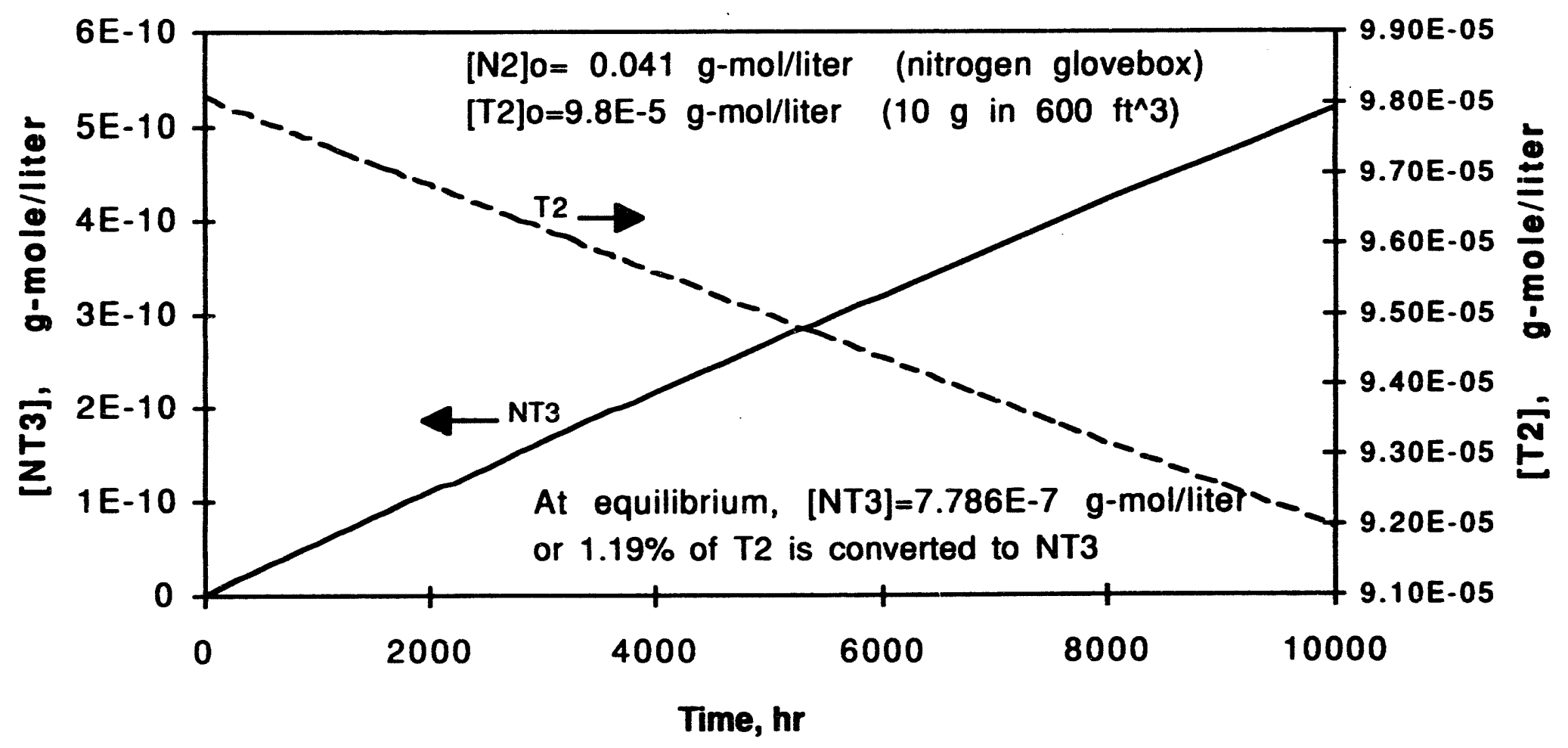

Figure 7. Tritiated Ammonia Formation in A Nitrogen Glovebox 


\section{Concentration Effect on NT3 Formation Rate}

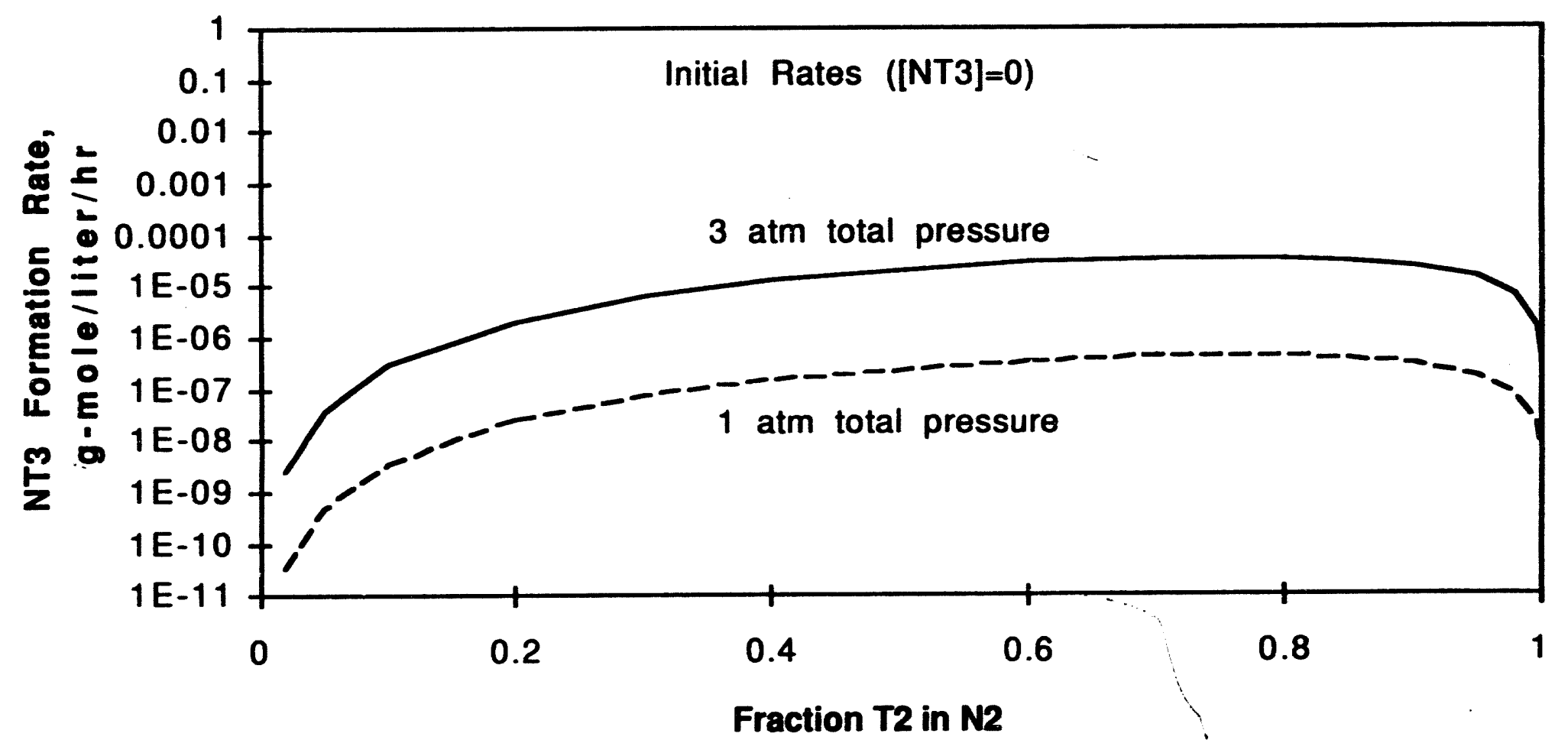

Figure 8. $T_{2}$ Concentration Effect on Tritiated Ammonia Formation Rate. 


\section{Tritlum Concentration Effect On Maximum Conversion}

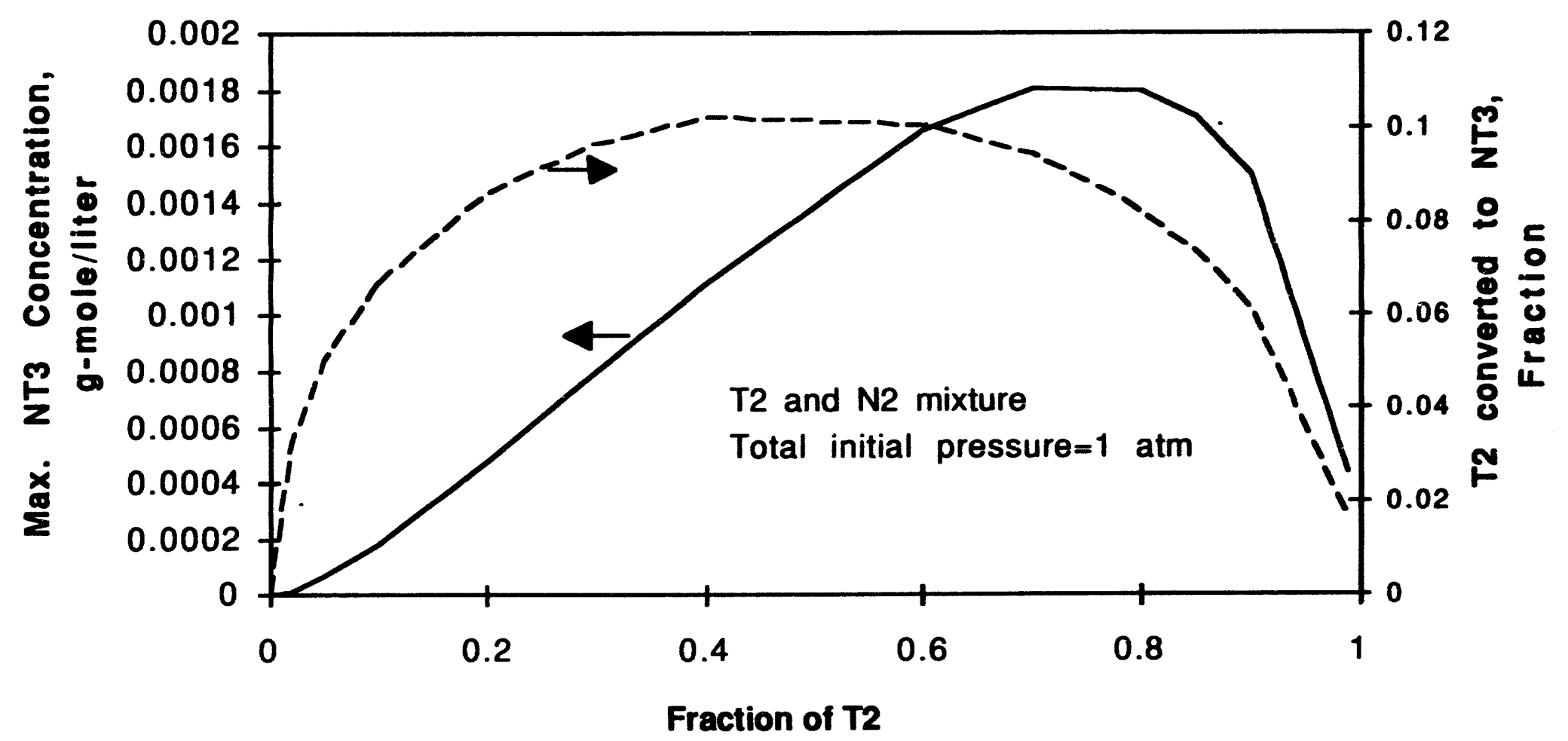

Figure 9. $\mathrm{T}_{2}$ Concentration Effect on Equilibrium $\mathrm{NT}_{3}$ Concentration and $\mathrm{T}_{2}$ Conversion 


\section{Experimental Data vs Calculation}

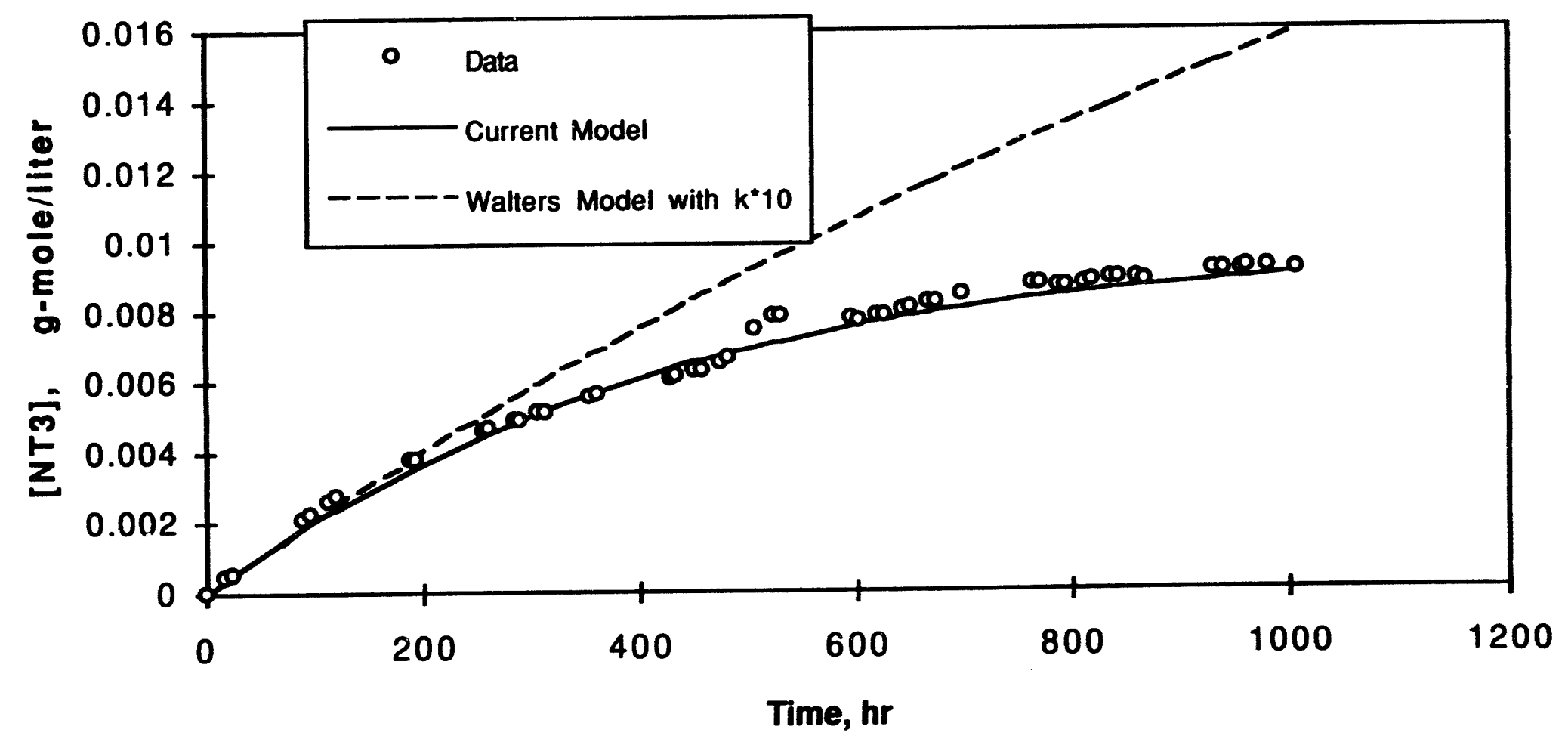

Figure 10. Current Model vs. Walters Model 
Appendix 1 Derivation of The Equation For Calculating $\mathrm{NT}_{3}$ Concentration From Experimental Data of Pressure, Temperature and Time.

The reaction equation is

$$
\mathrm{N}_{2}+3 \mathrm{~T}_{2}=====2 \mathrm{NT}_{3}
$$

Ideal gas law: where

$$
P^{*} V=n * R^{*} T
$$

P: pressure

$\mathrm{V}$ : volume

$\mathrm{n}$ : number of moles

$\mathrm{R}$ : gas constant

T: Temperature.

At time $=0$

Tritium partial pressure $\mathrm{PTr}=\mathrm{PTr}_{\mathrm{O}}$

Nitrogen partial pressure $P N=P_{0}$

Tritiated Ammonia partial pressure $\mathrm{PA}=\mathrm{PA}_{0}=0$

Total pressure $\mathrm{P}=\mathrm{P}_{\mathrm{O}}=\mathrm{PTr}_{\mathrm{O}}+\mathrm{PN}_{\mathrm{O}}+0$

and the concentrations are, in g-mole/liter:

$\left[\mathrm{T}_{2}\right]_{\mathrm{O}}=\mathrm{PTr}_{\mathrm{o}} /\left(\mathrm{R}^{*} \mathrm{~T}_{\mathrm{o}}\right)$

$\left[\mathrm{N}_{2}\right]_{0}=\mathrm{PN} /\left(\mathrm{R}^{*} \mathrm{~T}_{\mathrm{O}}\right)$

$\left[\mathrm{NT}_{3}\right]_{0}=\mathrm{PA}_{0} /\left(\mathrm{R}^{*} \mathrm{~T}_{0}\right)=0$

total moles $=\left[\mathrm{T}_{2}\right]_{0}+\left[\mathrm{N}_{2}\right]_{0}=\mathrm{P}_{\mathrm{o}} /\left(\mathrm{RT}_{\mathrm{o}}\right)$

At time $=t$

$$
\begin{aligned}
& {\left[N_{3}\right]_{t}=P A_{t} /\left(R^{*} T_{t}\right)} \\
& {[\text { He- } 3]_{\mathrm{t}}=2^{*}\left[\mathrm{~T}_{2}\right]_{\mathrm{o}} *\left[1-\exp \left(-\lambda^{*} \mathrm{t}\right)\right] \quad\left(\lambda=\mathrm{T} 2 \text { decay constant }=6.43 \mathrm{E}-6 \mathrm{hr}^{-1}\right)} \\
& {\left[\mathrm{T}_{2}\right]_{\mathrm{t}}=\left[\mathrm{T}_{2}\right]_{\mathrm{o}}-\left[\mathrm{NT}_{3}\right]_{\mathrm{t}} *(3 / 2)-[\mathrm{He}-3]_{\mathrm{t}}{ }^{*}(1 / 2)} \\
& =\left[\mathrm{T}_{2}\right]_{0}-\left[\mathrm{NT}_{3}\right]_{\mathrm{t}}^{*}(3 / 2)-\left[\mathrm{T}_{2}\right] \mathrm{o}^{*}\left[1-\exp \left(-\lambda^{*} \mathrm{t}\right)\right] \\
& {\left[\mathrm{N}_{2}\right]_{\mathrm{t}}=\left[\mathrm{N}_{2}\right]_{0}-\left[\mathrm{NT}_{3}\right]_{\mathrm{t}} *(1 / 2)} \\
& \text { total moles }=P_{t} /\left(R T_{t}\right) \\
& =\left[\mathrm{NT}_{3}\right]_{\mathrm{t}}+[\mathrm{He}-3]_{\mathrm{t}}+\left[\mathrm{T}_{2}\right]_{\mathrm{t}}+\left[\mathrm{N}_{2}\right]_{\mathrm{t}} \\
& =\left[\mathrm{NT}_{3}\right]_{\mathrm{t}} \\
& \begin{array}{l}
+2^{*}\left[T_{2}\right]_{0}^{*}\left[1-\exp \left(-\lambda^{*} t\right)\right] \\
+\left[T_{2}\right]_{0}-\left[N T_{3}\right]_{t}^{*}(3 / 2)-\left[T_{2}\right]_{o}^{*}\left[1-\exp \left(-\lambda^{*} t\right)\right] \\
+\left[N_{2}\right]_{0}-\left[N T_{3}\right]_{t}^{*}(1 / 2)
\end{array}
\end{aligned}
$$

Rearranging to give the final form of the equation:

$$
\begin{aligned}
{\left[\mathrm{NT}_{3}\right]_{t} } & =\mathrm{P}_{t} /\left(\mathrm{RT}_{t}\right)+\left[\mathrm{T}_{2}\right]_{0}+\left[\mathrm{N}_{2}\right]_{0}+\left[\mathrm{T}_{2}\right]_{0} *\left[1-\exp \left(-\lambda^{*} t\right)\right] \\
& =-\mathrm{P}_{t} /\left(\mathrm{RT}_{t}\right)+\mathrm{P}_{0} /\left(\mathrm{RT}_{0}\right)+\mathrm{PTro} /\left(\mathrm{R}^{*} \mathrm{~T}_{0}\right)^{*}\left[1-\exp \left(-\lambda^{*} t\right)\right] \\
& =(1 / R) *\left[-\mathrm{P}_{t} / \mathrm{T}_{t}+\mathrm{P}_{0} / \mathrm{T}_{0}+\left(\mathrm{PTr}_{0} / \mathrm{T}_{0}\right)^{*}\left[1-\exp \left(-\lambda^{*} t\right)\right]\right]
\end{aligned}
$$




\section{DISTRIBUTION:}

J. R. Knight, 773-A

T. Motyka, 773-A

J. R. Dollar, 232-H

A. F. Reichman, 773-A

M. W. Lee, 773-A

A. S. Horen, 773-A

J. E. Klein, 773-A

J. H. Scogin, 773-A

D. L. Hayes, 235-H

D. J. Green, 235-H

R. A. Pedde, 235-H

R. D. Buley, 235-H

T. R. Davis, 235-H

D. U. Randolph, $233-5 \mathrm{H}$

W. B. Wilson, 703-42A

TIM Office, 703-43A (4 copies) 

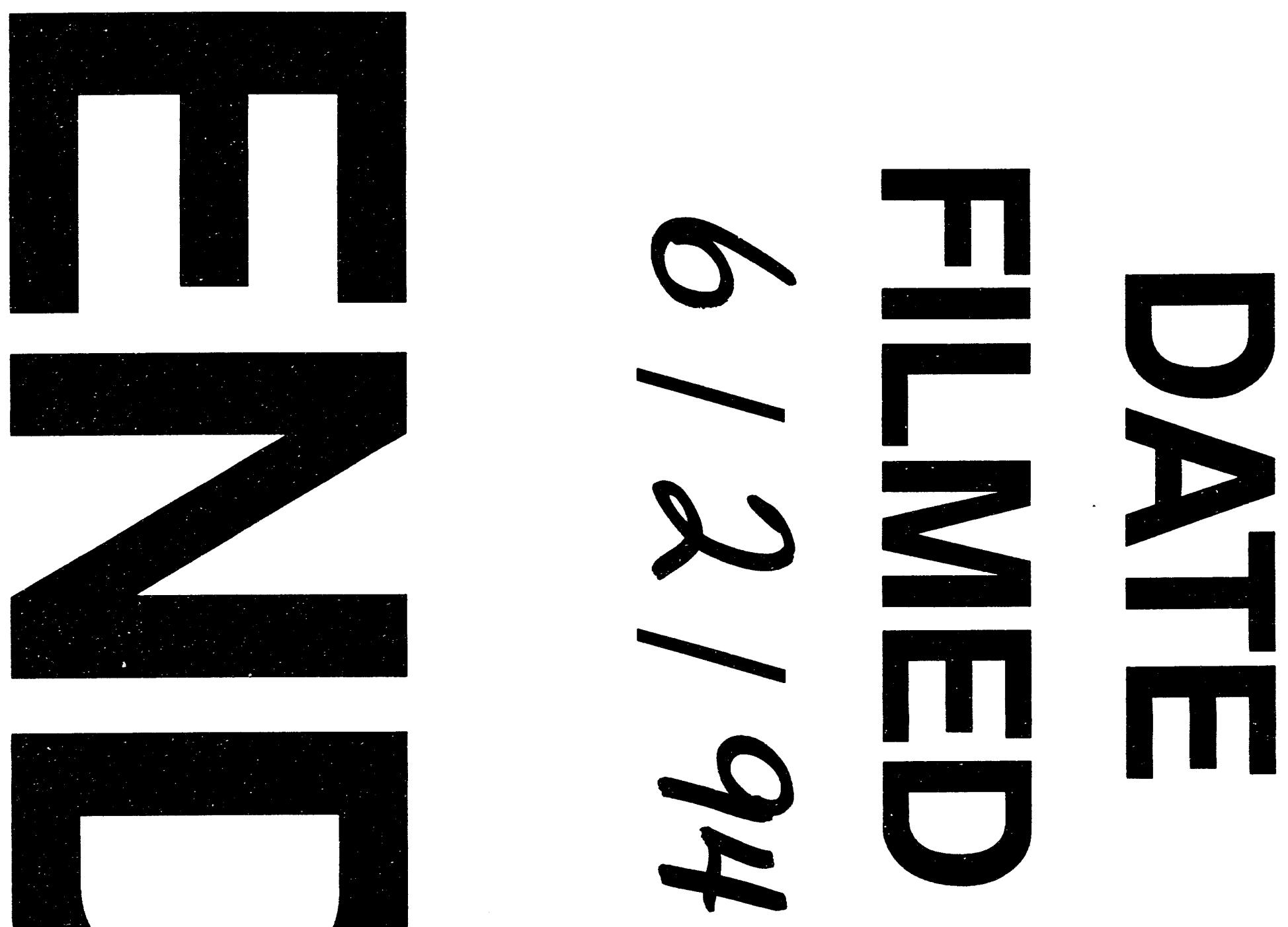
